\title{
A framework for understanding managerial responses to supply chain complexity
}

\section{$\underline{\text { Abstract }}$}

Purpose: In this paper we examine the nature of supply chain complexity and extend this with literature developed within the project domain. We use the lens of ambidexterity (the ability both to exploit and explore) to analyse responses to complexity, since this enables us to understand the application of known solutions in conjunction with innovative ones to resolve difficulties. This research also seeks to investigate how managers respond to supply chain complexities that can either be operationally deleterious or strategically beneficial.

Design/Methodology/Approach: We develop a descriptive framework based on the project management literature to understand response options to complexity, and then use interviews with supply chain managers in six organizations to examine the utility of this framework in practice. We ask the research question 'How do managers in supply chains respond to complexities?'

Findings: The case study data show first that managers faced with structural, socio-political, or emergent supply chain complexities use a wide range of responses. Second, over a third of the instances of complexity coded were actually accommodated, rather than reduced, by the study firms, suggesting that adapting to supply chain complexity in certain instances may be strategically appropriate. Third, the lens of ambidexterity allows a more explicit assessment of whether existing project management solutions can be considered or if novel methods are required to address supply chain complexities.

Practical Implications: The descriptive framework can aid managers in conceptualising and addressing supply chain complexity. Through exploiting current knowledge, managers can lessen the impact of complexity while exploring other innovative approaches to solve new problems and challenges that evolve from complexity growth driven by business strategy.

Originality/value: This study addresses a gap in the literature through the development of a framework which provides a structure on ways to address supply chain complexity. We evaluate an existing project complexity concept and demonstrate that it is both applicable and valuable in non-project, on-going operations. We then extend it using the lens of ambidexterity, and develop a framework that can support practitioners in analysing and addressing both strategically necessary supply complexities, together with unwanted, negative complexities within the organization and across the supply chain.

Key words: Strategic, complexity, supply chain, project, ambidexterity.

Paper Type: Research paper 


\section{Introduction}

The impact of complexity on organizational operations has long been a source of major concern for managers, with success rates of complex organizational endeavours remaining at disappointing levels across a number of sectors (e.g., Information Technology projects, Flyvbjerg and Budzier, 2011). Improving this represents a huge economic opportunity, yet remains a challenge despite significant investment in organizational processes and tools over recent decades. Ackoff (1979, p. 99) identifies "complex systems of changing problems that interact with each other" and calls such situations "messes" for managers to address. Resolutions to these messes are still frustratingly elusive.

Drawing from the literature on project complexity, this paper puts forth a framework that can assist practitioners and researchers in understanding the range of managerial responses that are available to address supply chain complexities. Through our review of the relevant literature and case research involving six UK service and manufacturing companies, this study contributes to the supply chain complexity body of knowledge by providing a structure that enables managers to understand 'how' they might respond to complexities they encounter. This work builds upon the existing research base, which considers the types and sources of supply chain complexity (Bode and Wagner, 2015; Bozarth et al, 2009; de Leuuw et al, 2013; Vachon and Klassen, 2002) and various strategies for addressing them (Serdarasan, 2012).

The relatively abstract nature of what constitutes 'complexity' has led to difficulties both in theorising response repertoires and in offering guidance for managers. Supply chain complexity is acknowledged as an increasingly important challenge that organizations need to address to reduce its deleterious impact (Bozarth et al, 2009; Giminez et al, 2012) whilst (perhaps counterintuitively) supporting and embracing the development of a competitive advantage (Aitken et al, 2016; Manuj and Sahin, 2011; Secchi and Camuffo, 2016).

In this paper, we investigate whether concepts and frameworks developed within the project complexity literature are applicable to supply chain contexts. Specifically, the work of Maylor and Turner (2017) in this journal provides a framework to understand complexity in terms of structural, socio-political and emergent dimensions linked to potential responses including planning and control, relationship development, and flexibility. We highlight the limitations of our knowledge in this area, and demonstrate that these concepts are also to be found within the supply chain literature. We ask the research question 'How do managers in supply chains respond to complexities?' We compare and contrast the project and supply 
chain complexity literatures to build a justification for taking a framework developed in one domain (project management) and evaluating its usefulness in another (supply chain management). Furthermore, by discussing the concepts of exploitation and exploration (March, 1991) whereby organizations can draw on existing knowledge or create new knowledge to address business challenges, we show how the lens of ambidexterity (the ability to achieve both) is beneficial in terms of conceptualising complexity and possible responses to it.

Drawing on the complementary perspective of ambidexterity (Kristal et al, 2010) and the simultaneous business demands of minimising the deleterious consequences of supply chain complexity while harnessing the potential competitive advantages it offers (Aitken et al, 2016), we develop a descriptive framework to understand managers' responses to supply chain complexities. This paper thus has two objectives. First, we look to determine if the existing frameworks for understanding complexity developed within the project domain are applicable to alternative contexts and, if so, to develop a more robust understanding of the various responses managers have for addressing supply chain complexities. Second, we seek to develop a descriptive, empirically-supported, framework for managing supply complexity that addresses the types of complexity faced by the organization, the range of management responses available, the strategic nature of the complexity challenge, and the degree of novelty required in the selected response.

This deductive research utilised project management complexity literature to formulate our research question. This led to the development of explicit a priori propositions to test the frameworks of project management in a supply chain complexity context (Ketokivi and Choi, 2014). The data from the qualitative case studies were used to amend or confirm the project management frameworks in the supply chain complexity context (Barratt et al, 2011).

The paper is structured as follows. First we review the relevant literature on project complexity, including frameworks that have been developed to investigate and understand complexity at the project level. This is followed by a review of the supply chain complexity literature. We then identify the overlaps and gaps between these bodies of work. We next review the literature on ambidexterity and ambidextrous responses.

We use this to develop a descriptive framework which addresses the type of complexity, whether the complexity to be addressed is deleterious or beneficial in nature (Aitken, et al., 2016), and the different managerial responses available. We then test the utility of the framework via six qualitative case studies from firms representing a variety of manufacturing and service organizations. We explain the case study methodology, including the sampling 
logic and the data gathering and analysis methods. We then describe our findings and subsequently present our conclusions and the implications for researchers and managers.

\section{Theoretical background}

\subsection{Project complexity}

Despite significant investment in project management processes, training, and professional Bodies of Knowledge (e.g., APM, 2012; PMI, 2017), it is widely acknowledged that project performance levels remain stubbornly low (e.g., Chaos Report, 2015; Engelbrecht et al., 2017). One cause of this is the inherent complexity of the work, which has been a key area of concern for a number of authors (e.g., Baccarini, 1996; Dvir and Shenhar, 1998; Jaafari, 2003; Pich, Loch and DeMeyer, 2002; Xia and Lee, 2005). The aim of these many researchers has not been to give a 'simple' solution to the difficulties project managers face by definition this is not feasible - but to provide analysis so that a more nuanced understanding may be obtained, thereby enabling more thoughtful responses to be crafted.

Williams (2005) calls for an understanding of what makes projects complex, drawing on the 'lived experience' approach. Cicmil et al. (2009) differentiate between the complexity in projects and the complexity of projects. The former relies on a complexity science approach, the latter on the managers' individual perspectives (i.e., a subjective view, Maylor et al., 2013). There is no accepted definition within the literature, with Maylor and Turner (2017, p. 1077) arguing that “one person's complex was another's complicated [italics added]". Ramasesh and Browning (2014) differentiate between complexity and complicatedness. The former includes element and relationship complexity, the latter they advise is more observer dependent. They use the example of complex code in a software application which is hidden by an elegant interface, thereby making it less complicated for the user. Using a different perspective, Uhl-Bien et al. (2007, p. 302) argue that

"If a system can be described in terms of its individual constituents (even if there are a huge number of constituents), it is merely complicated; if the interactions among the constituents of the system, and the interaction between the system and its environment, are of such a nature that the system as a whole cannot be fully understood simply by analyzing its components, it is complex [italics in original]."

Shenhar and Holzmann (2017), looking at 'megaprojects,' note the multiple factors that have been associated with project complexity, and acknowledge that there is no standard 
framework for project complexity assessment. They argue that "complexity is also subjective, that is, it also depends on the recipient's level of knowledge" (2017, p. 7), and that "by using such wide interpretation of complexity we may include everything that makes managing the megaproject difficult or challenging." This is the approach we take here also.

The systematic literature review of Geraldi, Maylor and Williams (2011) in this journal identified five distinct forms of project complexity, namely 'structural', 'pace', 'socio-political', 'uncertainty' and 'dynamic'. This was followed by Maylor et al. (2013) who created the Complexity Assessment Tool (CAT), built around three primary dimensions of complexity: structural (including pace), socio-political, and emergent (incorporating uncertainty and dynamic). The CAT takes the form of a questionnaire with which managers can readily assess the complexity of their own projects across these three dimensions.

According to the authors, structural complexity is "associated with size, variety, breadth of scope, the level of interdependence of people or tasks, or the pace of the work" (Maylor, et al. 2013, p. 46). Questions used to assess structural complexity address the definability and measurability of projects; the availability of required information, people and physical resources; and the degree to which the project is self-contained. In contrast, sociopolitical complexity is "associated with the project's importance, its people, power and politics, both within the project team and in the wider stakeholder communities" (Maylor, et al. 2013, p. 47). The authors measure this dimension via questions that address the degree of organizational alignment between the project and the organization's strategy, internal and external stakeholders, organizational structure, and culture. Last, the authors define emergent complexity as "expectations for stability" (Maylor, et al. 2013, p. 48) with regard to the structural and socio-political dimensions of project complexity. This can also include the challenge of the unexpected and 'unknown unknowns' (e.g., Ramasesh and Browning, 2014). In terms of the relevance of these to supply chains, structural issues can be considered in terms of balancing supply and demand, and the technical challenge of organizing logistics. Socio-political issues of stakeholder management and organizational politics are likely in any context, and the prospect of change and uncertainty may occur from internal or external sources. Our initial expectation therefore was that these categories would also be identifiable within a supply chain investigation.

Although the CAT allows the identification of different forms of complexity (and hence allows different categories of 'complex projects' to be distinguished), an underlying theory explaining how to respond to these was still absent. Maylor and Turner (2017) subsequently updated the 2011 literature review and also proposed that structural 
complexities could be aided by planning and control tools (e.g., APM, 2012; Meredith and Mantel, 2012; PMI, 2017), socio-political complexities via a focus on relationship-building (e.g., Park and Lee, 2014), and emergent complexities by enabling flexibility (e.g., Dyba and Dingsoyr, 2008; Highsmith, 2009). Planning and control responses include such tools as Work Breakdown Structure and Critical Path Analysis, well-established within the field, as well as other widely-available approaches that assist managers in tracking progress. In contrast, relationship-building efforts include "interpersonal skills of communication, conflict management, delegation, influencing, leadership, negotiation and teamwork" (Maylor and Turner, 2017, p. 1085). Flexible responses include allowed deviations from established processes and procedures and the incorporation of novel solutions based on managerial judgement. The project complexity discussion has parallels with the risk management literature (e.g., PMI, 2017, ch.11), although much of that body of work is focused more towards structural and more quantifiable issues. The complexity approach is intended to provoke conversations that likely incorporate more options than are identified in most organizations' risk registers.

The authors' workshop data, though, showed that management practices were in fact more diverse than expected, and that the three broad categories outlined were not necessarily limited to their 'corresponding' complexity. For example, a relational approach to structural complexity might be to prioritise relationships with key stakeholders to keep them informed of progress, and in an uncertain environment a strong focus on effective risk management and change control can reduce the likelihood of unwanted 'surprises.' Actual responses, therefore, are not limited to the 'diagonal' of the three-by-three model. This is indicated in Table 1.

\section{Insert Table 1}

Although Maylor and Turner (2017) argue that these three forms of management responses are used by managers in the project domain, as yet we lack a comprehensive view both of the prevalence of such responses, and their potential application to supply chain complexity. Further, it is implicit in the project literature that responses to complexity may be systematic (i.e., based on existing expertise) or may require novel approaches given the particular circumstances. Maylor and Turner (2017) raise this point and advocate further work using this ambidexterity lens. In light of this, we explicitly bring this to the fore shortly as a way to understand and analyse response choices. 


\subsection{Supply chain complexity}

As with the project management literature, researchers in the supply chain arena have looked to develop a better understanding of supply chain complexity and the repertoire of potential responses (Childerhouse and Towill, 2004; Perona and Miragliotta, 2004; Serdersan, 2013). Although the subjective view is not as explicit in the discussion as it is in the project literature, we incorporated the approach in this domain also. Building upon the literature, Bozarth, et al. (2009, p. 80) define supply chain complexity as "the level of detail complexity and dynamic complexity exhibited by the products, processes and relationships that make up a supply chain." According to the authors, detail complexity refers to "the distinct number of components or parts that make up a system," (2009, p. 79) (akin to structural complexity in the project domain) while dynamic complexity reflects “the unpredictability of a system's response to a given set of inputs, driven in part by the interconnectedness of the many parts that make up the system" $(2009$, p. 79$)$. This has similarity to structural complexity in relation to interconnectedness, yet the unpredictability is consistent with emergent complexity. Beyond the dual nature of supply chain complexity, other important supply chain complexity themes address the level of analysis, whether or not supply chain complexity should be accommodated, and appropriate organizational responses. We discuss each of these in turn.

\section{Systems Level vs. Business Unit Supply Chain Complexity.}

Researchers have tended to study supply chain complexity at either the multi-organization, systems level (Choi, et al., 2001; Holland, 1995), or at the individual business unit level (Aitken, et al, 2016; Bozarth, et al., 2009). At the systems level, the primary focus has been on how the many organizations that make up a supply chain respond as a whole to the resulting levels of detail and dynamic complexity. The literature on complex adaptive systems (CAS) has featured prominently in these discussions (Choi et al., 2001; Holland, 1995). The CAS literature is notable because it suggests that responses to supply chain complexity can emerge organically through shared interpretive and behavioural schema, as well as through more formal mechanisms such as collaborative planning, forecasting and replenishment (CPFR) (Seifert, 2003).

In contrast, the business unit (BU) perspective considers supply chain complexity from the vantage point of an individual firm (Aitken et al., 2016; Bozarth et al., 2009). This is the dyadic perspective (Fynes and Voss, 2002) adopted in this paper, viewing the complexities managers face within their own organizations and at the interfaces, rather than 
the wider network. We are interested in issues over which the managers (may) have some control, rather than broader systemic effects.

\section{'Dysfunctional' vs. 'strategic' supply chain complexity.}

At the BU level, participation in a supply chain is not assumed as it is in the systems-level literature. Rather, in an open economy, individual BUs have some choice of what downstream customers and upstream suppliers they will partner with, and as a result, what supply chain complexities they are willing to take on. Hence, it is important that an individual firm's managers are able to distinguish between strategically necessary and unnecessary sources of supply chain complexity, and respond accordingly.

The deleterious performance impact of supply chain complexity has been wellestablished in the literature (Bozarth et al., 2009; Heim et al., 2014; Vachon and Klassen, 2002). However, individual organizations may still need to accommodate some amount of supply chain complexity as part of the overall business strategy. A classic example is Fisher's 1997 article, "What is the right supply chain for your product?", in which the author holds that innovative products require "market-responsive" supply chains (i.e., less 'efficient', and characterized by greater use of capacity and inventory buffers). Gottfredson and Aspinall (2005) follow a similar theme, arguing that the ideal level of product line complexity can be determined by starting with the simplest product possible and increasing complexity via more features and options until marginal costs equal marginal revenues. The implication in both works is that higher levels of supply chain complexity can be strategically beneficial under the right conditions. The idea of 'beneficial complexity' may initially appear counterintuitive, but the logic is well-developed within the literature.

Aitken, et al. (2016) were the first to make explicit the distinction between what they refer to as dysfunctional and strategic supply chain complexity. The authors define dysfunctional complexity as "supply chain complexity that is not required to carry out the BU's business strategy and prevents the organization from achieving a higher level of performance" (2016, p. 761). In contrast, strategic supply chain complexity represents "a level of supply chain complexity that is required to carry out the BU's business strategy and therefore must be absorbed by the organization's manufacturing and supply chain activities." (2016, p. 761). Examples of dysfunctional complexity include excessive cycle times, unreliable supplier quality levels or lead times, and uncontrolled product proliferation. Examples of strategic complexity may include purposefully higher levels of customization, a globally diverse supply base, or an expanded set of targeted customers. For clarity of 
language we will refer to dysfunctional and strategic complexity as 'deleterious' and 'beneficial' respectively.

\section{Complexity Reduction versus Complexity Accommodation}

We noted earlier that the project complexity literature as characterised by Maylor and Turner (2017) divides organizational responses to complexity into three main types: planning and control, relationship and flexibility responses. The supply chain complexity literature has taken a different tack, broadly dividing responses into complexity reduction and complexity accommodation responses.

Aitken, et al. (2016) argue that BUs should look to reduce sources of dysfunctional (deleterious) complexity while accommodating strategically beneficial ones. Furthermore, building on Galbraith (1974, 1977), BUs can accommodate complexity in one of two ways: “1) create slack resources or self-contained tasks that absorb the effects of uncertainty, or 2) invest in information systems or lateral relations [e.g., relationships] that enhance the organization's ability to process information during task execution. [emphasis in original]" (Aitken, et al., 2016, p. 763). For instance, extra production capacity and inventories are illustrative of slack resources that serve to buffer an organization from uncertainty, while advanced planning tools and information-sharing among supply chain partners improve the organization's ability to react to new conditions.

\subsection{Overlaps and gaps between supply chain and project complexity literature}

The complexity literature is extensive in both the project and supply chain management domains, yet to date these do not appear to have been brought together to provide a basis for managers to address complexity utilising the knowledge and potential synergies of the two areas. The two domains are distinctly different, with projects necessarily being time-limited and often having dissimilar drivers to ongoing supply chain operations, but within the SC literature there is evidence that the same forms of complexity may indeed exist.

We examine overlaps between supply chain and project complexity in Table 2 which identifies on the horizontal axis the three kinds of complexity (structural, socio-political and emergent), with response options (planning and control, relationship development, and flexibility) on the vertical axis. Using examples experienced regularly in supply chains we build on Maylor and Turner (2017) to show that the principles appear to correspond to the SC context. 


\section{Insert Table 2}

The literature on the structural dimension of supply chain complexity reflects the detail aspects that have been widely discussed, with several authors highlighting the consequences of increased structural complexity on performance (Masson et al, 2007; Perona and Miragliotta, 2004; Serdarasan, 2013), measurement/modelling (de Leeuw et al, 2013; Inman and Blumenfeld, 2014; Isik, 2010), and risk (Ge et al, 2016; Gunasekaran et al, 2015).

In terms of the socio-political dimension, the literature recognises that both internal and external integration solutions can improve the performance of the supply chain (Chakraborty, 2016; de Leuuw et al, 2013; Flynn et al, 2010; Frohlich and Westbrook, 2001; Masson et al, 2007; Novak and Eppinger, 2001; Sarpong, 2014; Schoenherr and Swink, 2012; Yang et al, 2007). The external integration aspect of supply chain management is a well-developed area of research, therefore its role in managing complexity is logical and expected. However, internal integration through alignment of objectives and co-ordination of information flows between functions (de Leeuw et al, 2013) has had significantly less attention in the supply chain complexity literature.

Emergent (dynamic) complexity, the third dimension on the horizontal axis in Table 2, which results from changes in structural aspects, is highlighted in several papers. Increasing scale can lead to the "emergence of disruptive events" (Bode and Wagner, 2015, p. 217), greater uncertainty (Huatuco et al., 2010; Thome et al., 2016; Vachon and Klassen, 2002), reduced performance (Bozarth et al., 2009) and more complicated decision-making (Manuj and Sahin, 2011). Higher levels of interconnectedness in terms of external integration can generate "emergent behaviour that cannot be predicted from the individual system components" (Isik, 2010, p. 3683) leading to behaviour that could appear to be "chaotic or unpredictable" (Wu et al, 2013, p. 657). Chakraborty (2016), however, highlights the positive aspect of increasing complexity as it can give rise to increasing levels of interdependence between supply chain members. Emergent complexity due to changes in internal integration was not discussed in any of the papers except for Bode and Wagner (2015), who suggested that an increase in number of departments could lead to higher degrees of complexity.

Examples of approaches used to reduce and manage SC complexity, the vertical axis of Table 2, include sales and operational planning (Ivert and Jonsson, 2014), customer and supplier relationship management (Christopher, 2016), product proliferation reduction (Gottfredson and Aspinall, 2005), and the use of third party sourcing agents together with agility (Masson et al., 2007). Aitken et al., (2016), as noted, posit that organizations can 
accommodate supply chain complexity through slack resources, investment in information systems, or relationship-building. Accommodating complexity does not reduce the level of complexity per se but lessens its impact on the performance of the supply chain.

To summarise, the literature on project complexity identifies three dimensions of complexity: structural, socio-political and emergent (Maylor et al., 2013), with three broad categories of response (Maylor and Turner, 2017). Additionally, the supply chain literature recognises that some complexities are beneficial as they represent a deliberate strategic choice. Instead of blindly driving down supply chain complexity which could decrease overall competitiveness (Choi and Krause, 2006), BUs that can accommodate this complexity may derive a competitive advantage (Bozarth et al., 2009; Fisher, 1997; Isik, 2010) and in some instances outperform organizations that focus only on reduction (Ashmos and Duchon, 2000).

We thus see the benefits of the complexity approach (showing types of complexity and potential responses) from the project management domain, which appears to align with evidence from supply chain studies. However, an initial objective of the empirical phase of our investigation was to ensure that this classification system was justified outside the project context. In terms of response, the reduction approach is the accepted technique within project management (PM), and it is not clear that the idea of strategically beneficial complexity is as applicable in this environment, though one could argue that certain project outcomes necessarily require high levels of project complexity and trying arbitrarily to oversimplify the project could result in longer time frames or less satisfactory results. However, bringing together the two streams of literature allows us to analyse better the forms of complexity that supply chain managers face and to categorise and understand the types of responses they implement.

\subsection{Ambidexterity}

With regard to organizational learning, March (1991) distinguished between 'exploitation' (refining and using existing knowledge) and 'exploration' (innovation, problem-solving and creating new knowledge), and suggested that these two activities competed for limited organizational resources. Examining this tension has led to a large body of work on ambidexterity which seeks to understand how organizations may reconcile the opposing requirements of the two concepts. The ability to accommodate both exploitation and exploration has been associated with a range of financial and other performance benefits (see Birkinshaw and Gupta, 2013; Junni, et al., 2013; O'Reilly and Tushman, 2013; and Turner et 
al., 2013 for reviews). The literature identifies three high-level approaches to achieving ambidexterity. In temporal ambidexterity (Tushman and O’Reilly, 1996), exploitation and exploration are sequential, i.e., the organization moves from one dominant mode to the other, often as a response to a change in market conditions. In structural ambidexterity (O'Reilly and Tushman, 2004), exploitative and exploratory aspects are configured and run separately. Finally, contextual ambidexterity (Gibson and Birkinshaw, 2004) is a behavioural response in which individuals within a business unit demonstrate not only alignment to the predefined goals but also adaptability as required by the situation at hand, based on their judgement at the time.

Ambidexterity has been applied to the project domain based on the logic that projects frequently require existing organizational expertise, consistent processes and systems (exploitation), yet necessarily involve some degree of uniqueness, novelty and knowledgegeneration (exploration) (Geraldi, Kutsch and Turner, 2011). Brady and Davies (2004) also show how organizations can learn through 'vanguard' projects (exploration), then refine this knowledge over time and exploit it systematically in future projects. Ambidexterity at the individual managerial level (Turner and Lee-Kelley, 2013) and project team level (Liu and Leitner, 2012; Turner et al., 2016) has also been shown to be significant for project performance. In hierarchical analyses, Pellegrinelli et al. (2015) show that exploration can be understood more at the programme level with exploitation being enacted at the project level within those programmes.

Ambidexterity is also an important area of study within the supply chain literature and it has been shown to aid performance, inter-organizational relationships and flexibility (Blome et al., 2013; Eltantawy, 2016; Im and Rai, 2008; Kristal et al, 2010; Lee and Rha, 2016; Rojo et al., 2016). Even though ambidexterity has emerged as an appropriate lens for exploring supply chain performance, there appears to be little that addresses this from a supply chain complexity perspective.

\subsection{Ambidexterity as a response to complexity?}

Both the project and supply chain management literatures identify the complexities that managers in those fields face. Interestingly, the project management literature generally treats complexity as an issue ideally to be resolved or reduced, whereas the supply chain complexity literature specifically categorises complexity as either 'dysfunctional' (i.e., ineffective processes, procedures and errors) with deleterious consequences (Childerhouse and Towill, 2004; Heim et al., 2014; Hoole, 2005) or as 'strategic' (beneficial), representing 
a level of supply chain complexity that is required to carry out the strategy of the business and which therefore must be accommodated (Aitken et al, 2016). We posit that both the 'minimisation' and 'accommodation' options may be understood in terms of exploitation and exploration.

For an exploitative response, systems and procedures can be put in place to help mitigate the impact of complexity. Maylor and Turner (2017) describe the 'planning and control' responses as being applicable to all three forms of complexity (i.e., applying known or planned resources), so this logic appears sound. For example, if the number of suppliers and range of products to be managed increases (whether through deliberate choice or not), the implementation of a more sophisticated IT system is a suitable response to support this structural complexity. Maylor and Turner (2017) also provide support for exploratory responses being suitable when faced with complexities. The nature of the flexibility response and the utilisation of agility and change-related activities imply that exploration is inherent in these managerial actions. Problem-solving and the generation of new knowledge is appropriate and to be expected under such circumstances.

\section{Descriptive Framework}

In this section, we summarise the previous discussion of our descriptive framework to understand the nature of responses to supply chain complexities. The first part of the framework (Table 2) adapts the work of Maylor and Turner (2017) to provide a comprehensive view of three distinct dimensions of complexity that are rarely if ever covered simultaneously in the supply chain complexity literature. Specifically, structural complexity captures the degree of detail complexity found within the supply chain (Bozarth, et al., 2009), while socio-political complexity addresses the degree of intra-organizational and interorganizational alignment required to carry out supply chain activities. Finally, emergent complexity captures expectations for stability across the other two dimensions, including the dynamic aspects arising from the interconnected elements (Bozarth, et al., 2009). The second part of the model (Table 3) derives from the ambidexterity literature to illustrate how managers can either exploit existing knowledge or explore innovative solutions to reduce or accommodate supply chain complexities, depending on the strategic needs of the business.

\section{Insert Table 3}


Consistent with Maylor and Turner (2017), the model divides management responses to complexity into three broad categories: planning and control, relationship development and flexibility responses. This feature of the framework directly addresses Aitken et al.'s (2016) call for a more structured understanding of the response mechanisms and patterns available to supply chain managers. The cells in both Tables 2 and 3 include examples of responses matched to the different complexity dimensions and strategic nature of the complexity faced by a firm. As we noted earlier, these are not meant to be exhaustive, but to illustrate the logic of the model. In line with Maylor and Turner (2017), we do not propose that appropriate responses in Table 2 will be limited to those 'on the diagonal', rather, each dimension of complexity may be addressed broadly, based on situational requirements.

Together, the two parts of the model provide managers and researchers with a framework that can be used explicitly to consider:

1. The type of supply chain complexity faced by the organization: structural, sociopolitical, emergent (Maylor et al., 2013).

2. The form of management response: planning and control, relational, flexibility (Maylor and Turner, 2017).

3. The strategic nature of the complexity faced by the organization: deleterious vs. beneficial (Aitken et al, 2016)

4. The nature of the response: exploitation or exploration (March, 1991).

Based on both the project management and supply chain complexity literatures and the anticipated parallels between the two, we therefore suggest two research propositions to be empirically tested:

Proposition 1 - We expect the three dimensions of complexity (structural, socio-political and emergent) and associated responses identified in the project management literature (planning and control, relationship development, and flexibility) to be present for firms dealing with supply chain complexity.

Proposition 2. - We expect to see firms employ an ambidextrous approach to managing both deleterious and strategically beneficial drivers of supply chain complexity. 
We now describe the methodology we used to evaluate these propositions and test the efficacy of our framework, based on a cross-industry sample of firms.

\section{Methodology}

Our initial objective was to establish that the forms of complexity identified within the project literature and the resulting response framework (Maylor, et al. 2013; Maylor and Turner, 2017) could be used within a supply chain context. With this background, we sought to understand how managers actually respond to supply chain complexity and to test the utility of the descriptive framework discussed above, using a subjective approach. Voss et al. (2002, p. 195) advise that "[c]ase research has consistently been one of the most powerful research methods in operations management", and Meredith (1998) highlights the greater understanding and depth that can be obtained via this method. The use of interviews and a subjective approach was used to investigate the 'lived experience' (Williams, 2005) of the managers in the organizations who address supply chain complexity issues, in line with the rationale of Cicmil et al. (2009), Maylor and Turner (2017) and Shenhar and Holzmann (2017). This enabled a far more detailed analysis of the what and how of the managerial response to SC complexity.

We undertook case studies with six UK-based organizations to investigate managerial responses to supply chain complexity and see if the PM concepts could be applied usefully. Interviews were conducted over a six-month period in 2016 with each interview lasting between 30 and 90 minutes depending upon the knowledge and breadth of scope of the individual. Two researchers were involved with developing the research protocol, collecting and coding the interviews that were conducted. We categorised these responses with regard to the type of complexity, management response, strategic nature of the complexity, and whether the response involved the application of existing or new knowledge.

Feedback was provided to the firms on completion of the study. The sample size means that the investigation could not be exhaustive; however, it does have theoretic generalisability as it offers the opportunity for insight into the way managers in supply chains respond to complexities. Testing the project management frameworks on a range of populations also increases generalisability (Meredith, 1998). The individual cases were selected through a convenience sample as the researchers were aware, through previous discussions, that the phenomena under investigation were being experienced by the firms. Each case was facing 
increased levels of customer demand heterogeneity, either in the form of customised products and/or tailored services. Researchers have identified complexity from these external sources as being sources of detail and dynamic complexities leading to internal operational and supply chain challenges (Bozarth et al, 2009; Hayes and Wheelwright, 1979). The six organizations and the context of the complexity which their business operations face are as follows (further detail is also given in Table 4):

1. Food Co. (FC) is a part of a global manufacturer of ready meals servicing supermarkets and catering companies. Over the last four years the number of SKU's has doubled as customers require more customised products with shorter life cycles, and this has led to the expansion of the operation from one to two sites.

2. Move Co. (MC) is an established multi-national distributor of parcels and a major competitor within this market. The market has become increasing competitive over the last 10 years as the sector grows through the boom in on-line sales. The number of customers and delivery points has also increased in terms of both $\mathrm{B} 2 \mathrm{~B}$ and $\mathrm{B} 2 \mathrm{C}$ clients. The firm operates from over 15 Regional Distribution Centres in the UK to deliver the service of this internet-driven market.

3. Restore Co. (RC) is a specialist restorer and repairer of vintage cars. This growth market has seen over $£ 600 \mathrm{~m}$ in total being spent on vintage vehicles in 2016 in the UK. The volume of work has led to a doubling of production space in the last 18 months. The work content of each customer's vehicle is often unknown until it arrives on-site for inspection. Simultaneous with customer demands for reduced turnaround times, the company is faced with increased levels of schedule instability and a supply chain that is populated with unreliable suppliers.

4. Wood Co. (WC) manufactures standard and bespoke timber and plastic furniture products for small retailers and on-line consumers. Distributors and manufacturers to Wood Co. have begun to source in the Far-East leading to longer delivery times and higher minimum order quantities. These detail and dynamic complexity (Bozarth et al, 2009) changes are challenging the firm's ability to supply bespoke products on a short lead-time and in a cost-effective manner.

5. Crash Co. (CC) operates across two production sites to repair vehicles which have been involved in accidents for insurers, large private and public organizations, and consumers. The challenge facing the business is the unilateral changes in service level agreements by insurers creating schedule instability and inevitably shorter turnaround times. 
6. Light Co (LC) is a manufacturer of lighting products for the industrial and commercial sectors. With the advent of new LED technology the firm has had to re-engineer its historical range of products while introducing new items which can satisfy customers' demands for longer-life offerings. These changes have rapidly expanded the firm's product portfolio, more than doubling the number of SKU's. This has expanded the supply base as well as the number of personnel involved in managing the supply chain.

The selected case study firms face increasing levels of supply chain complexity within their organization and across their supply chain interfaces. This provided the opportunity to build upon previous case study research (Aitken et al, 2106; Maylor et al, 2013; Maylor and Turner, 2017), thereby strengthening "the precision, the validity, and the stability of the findings" (Miles and Huberman, 1994, p. 29). Multiple case studies also support investigators in guarding against researcher bias while providing external validity (Voss et al, 2002; Yin, 2014).

Selected managers from each firm were asked to provide examples of supply complexities they faced (i.e., "What makes your work or supply chain complex or difficult to manage?"). The questions were not aimed at identifying SC projects, but the ongoing operations with which they were involved. These managers were chosen based on their experience addressing supply chain complexity across organizational interfaces (suppliers and customers) and internally inside the operation, rather than focusing on wider, systemic, supply chain issues over which they could exert little influence. This therefore provided the basis for understanding "the conditions under which the construct or theory operates with" (Miles and Huberman, 1994, p. 29). We conducted the investigation through on-site individual interviews. The list of participants (including their tenure in the position) is shown in Table 4.

The interview protocol reflected the research question, and focused on what made the supply chain complex or difficult to manage, what managers did about each difficulty, whether this was something they would normally do or whether it was an innovation, and the effects these actions had. Multiple interviews were conducted within each company to enhance the reliability of the data collected. Each interview was recorded, transcribed and coded utilising NVivo. The interview data were coded according to the facets discussed above: type of complexity (structural, socio-political, emergent); response (planning and control, relational, flexibility); strategic nature of the complexity (deleterious versus 
beneficial); and whether the chosen response represented the application of existing or new knowledge (exploitation or exploration).

\section{Insert Table 4}

\section{Results}

The coding allowed us to analyse for the presence of the various types of supply chain complexity and responses that we identified within the literature review. In terms of the types of complexity, we found a majority of the supply chain complexities identified by the respondents to be structural in nature $(65 \%)$. Socio-political and emergent complexities were noticeably fewer, at $12 \%$ and $23 \%$ respectively. Interestingly, this is in contrast to the work of Maylor et al. (2013) and Maylor and Turner (2017), who found socio-political complexities to be more prevalent in projects. One possible explanation is the relatively small size of some of the case organizations. Specifically, as smaller businesses, they may be less likely to have high levels of departmentalisation, and therefore be less likely to face the same level of intraorganizational barriers as large organizations. Given the small sample size of this study, we cannot as yet attribute this finding to firm size or context but we note it as part of the analysis. We identified earlier the dearth of literature addressing socio-political complexity within the supply chain management literature, but it was clearly evident within the case firms. For example, when the Operations Manager of Move Co. was asked about the most challenging aspect of the supply chain, he did not list technical or logistical issues but replied simply "The people."

Responses were predominantly centred on planning and control approaches, likely linked to the prevalence of structural complexities identified by the respondents. Planning and control responses represented $56 \%$ of the coding, with relationship-development and flexibility forming $17 \%$ and $27 \%$ respectively. That said, our findings from the cases were instructive. Analysis of the complexities and responses showed that all nine of the permutations offered by Maylor and Turner (2017) were indeed identified, and representative examples of these from the different case organizations are given in Table 5 to show the kinds of responses implemented.

\section{Insert Table 5}


Several other observations could be made from the analysis. First, some of the complexities identified had more than one response type. For example, seeking new suppliers (structural) was addressed by searching online (planning and control) as well as drawing on existing relationships to identify potential new sources. Responses could therefore straddle more than one option in Table 5. Second, we noted that some responses were designed to pre-empt complexity rather than respond after the fact. A common example of this was to avoid potential future complexity by building relationships with suppliers. This pre-emption aspect - especially with regard to socio-political complexity - is not prevalent within the literature, yet is common practice and identified as a valuable use of time by the managers.

With regard to the strategic response to the complexity (reduce or accommodate) and nature of the actual response (exploitation or exploration), our findings were also instructive. $63 \%$ of the coding was for reduction, with a corresponding $37 \%$ for accommodate. Although this was a limited sample size study and therefore the results may not be generalisable, the fact that the respondents sought to accommodate more than one-third of the identified supply chain complexities highlights the strategic importance of many of the complexities identified, and demonstrates why it is incorrect to label complexity as necessarily deleterious. As one Improvement Manager noted:

"Complexity gives competitive advantage. If we can manage it well and we can provide that diversity of products or meet the variable demands, it is a great advantage to us... Complexity is what makes the business dynamic. If it was simple we would have everyone entering the industry."

Although the idea of a 'beneficial complexity' may seem like an oxymoron, this is a clear and concise example and explanation of what Aitken et al. (2016) identify and what it means to practising managers.

Two-thirds of the responses were coded as exploitative, with the remaining third being exploratory in nature. The role of innovation in responding to complexity is therefore vital, and our results highlight the importance of considering both exploitative and exploratory approaches. This is a finding not readily apparent in the complexity literature to date, and would appear to offer an interesting perspective to pursue in future investigations.

Not all coding was clear-cut. It has been recognised that exploitation and exploration can be difficult to distinguish when activities have elements of both (Turner and Lee-Kelley, 2013). Similarly, firms can simultaneously seek to reduce and accommodate supply chain complexity. For instance, Move Co. schedules 10,000-15,000 collection points a day all 
across the UK and aims to minimise the complexity of this, but the company also embraces one-off requests for customer pick-ups despite this being only a tiny fraction of their business. Considering 'reduce/accommodate' as 'either/or' may therefore be a limitation.

We categorised the managers' responses and representative examples are shown in Table 6. This shows that all four quadrants are represented. In addition, all three forms of complexity (structural, socio-political, emergent) are found within each quadrant. It was unclear at the outset what the data would reveal here, and the identification of all the supply chain complexity and response permutations indicates that the management of complexity is multifaceted and far from 'one-size-fits-all'.

\section{Insert Table 6}

As discussed earlier, this research was based on taking a complexity model from the project management domain and testing it, alongside the exploitation / exploration concepts, in the context of supply chains. Intriguingly, the case results show that many of the responses identified in our framework did manifest themselves in practice, yet it is not apparent that there are any themes or rules that govern the choice of response. Distinct patterns of cooccurrence of codes (King, 2004) were not evident, indicating that 'optimal' responses may not be selectable in advance or amenable to generalisable analysis or directions. We return to this point shortly.

\section{Discussion and Implications}

In this paper, we applied concepts and frameworks developed in the project complexity literature to understand better the response repertoires available to address supply chain complexity. Maylor and Turner (2017) show that project complexities can be categorised into structural, socio-political and emergent dimensions, and offer forms of solutions that can be adopted. They also advocate removing, reducing or 'running with' complexities encountered.

We showed that socio-political complexity at the managerial level is not an existing theme within the SCM complexity literature, whereas the notion of beneficial complexity due to deliberate strategic choice is not discussed within the project literature. We also built on previous work to incorporate the ideas of exploitation and exploration (March, 1991) as a way of better understanding the nature of responses managers implement. 
Based on the literature reviews, we developed a framework and put forth two research propositions that 1) argued that the three forms of complexity and three types of responses identified in the PM literature would manifest themselves in supply chain complexity environments as well, and 2) managers addressing supply chain complexity would use an ambidextrous approach when implementing responses. Our empirical data obtained from six qualitative case studies showed that the descriptive framework illustrated in Tables 2 and 3 can be used to gain deeper insight into what managers do when faced with supply chain complexity. We found examples of all three forms of supply chain complexity (structural, socio-political, emergent), as well as all three forms of response (planning and control, relationship development, and flexibility). In addition, the case data showed all nine crosspermutations (Table 5), indicating that Maylor and Turner's framework is applicable to supply chains as well as projects.

The findings to date do not indicate that there is one single 'right' way to manage complexities that are experienced, and no clear patterns were observed. From the concepts derived from the literature, we have demonstrated that three forms of complexity exist, three forms of response are enacted, managers seek to accommodate some complexities yet reduce others, and their responses can draw on existing knowledge, yet also incorporate new solutions where deemed appropriate. The propositions were therefore supported.

In effect, managers have a wide repertoire of potential responses and their decisions are based on situational judgement and tacit experience. In the language of Ackoff (1979), supply chain reality is 'messy' and most certainly not amenable to simple resolution. However, we believe that the practical benefit of this work is that it offers a way to articulate the nature of the problem more clearly, and allows a structured approach to identifying potential solutions. If managers can ask straightforward questions with their teams, this can aid in generating a shared understanding of the challenges and help generate agreement on solutions. As supply chains are ongoing operations, this cannot be a one-time event, but can be scheduled on a regular basis as determined by the particular context. We suggest asking the following:

1) What kind of problem is this? (structural, socio-political, emergent)

2) Is this complexity deleterious or beneficial? Do we want to reduce it or find a way to accommodate it?

3) What type of response would make sense? (plan and control, relational, flexibility) 
4) Is this something we have encountered before, or do we need to find a novel solution? (exploit, explore).

This paper makes a number of theoretical contributions as well. First, we demonstrated the benefits of incorporating project complexity concepts into the supply chain context. The framework of Maylor and Turner (2017) appears to offer an analysis tool that is valuable, and specifically brings in the concept of socio-political complexity which has not been addressed within the SCM complexity literature, yet was identified by the managers within the case organizations as important (see Table 5).

Second, over a third of the instances of complexity coded were accommodated, suggesting they were strategically important to the particular study firm. This is consistent with a growing understanding within the literature that supply chain complexity has duality in its nature (Aitken et al, 2016; Bozarth et al, 2009; Choi and Krause, 2006; Manju and Sahin, 2009). The singular pursuit of reducing and removing complexity can diminish the competitive opportunities which may exist. This was clearly demonstrated by managers in Food Co. and Move Co. who recognised the competitive gains that expanding the product and service offering brings to customers. The positive aspects of increased complexity are not recognised within the project literature; however, it may be beneficial in that context also.

Third, the lens of ambidexterity allows a more explicit assessment of whether existing solutions can be considered or if novel methods are required to address supply chain complexities. This level of discussion appears to be missing from the existing supply chain complexity literature yet it offers a greater level of detail to the analysis and promotes superior understanding of potential solutions. Operations academics have begun to utilise the ambidexterity concept as a framework to develop a greater understanding of "how operational routines and capabilities are renewed and realigned" (Patel et al, 2012, p. 202) and how supply chain relationships can be developed (Kristal et al, 2010).

Light Co. demonstrated the consequences of managing the supply base in an ambidextrous manner when the Financial Director highlighted a change in internal integration management due to the pace of technological changes. This change in governance was similarly found by Blome et al. (2013) when investigating the impact of technology on ambidexterity in supply chains. Kristal et al. (2010) also highlight the temporal aspect of ambidexterity with organizations addressing short-term issues through exploitation as well as looking to the future by exploring new approaches. An ambidextrous approach to managing complexity was, for example, demonstrated by Food Co. through stabilising price movement 
with suppliers to minimise complexity while planning to increase manufacturing flexibility to embrace growth in the product portfolio.

However, research recognising the multi-faceted dimensions of complexity and the need to develop supply chain responses and understanding which move beyond the structural aspects is largely missing. Our findings highlight that firms develop complementary competencies to address structural, socio-political and emergent complexity in the context of minimising or embracing that complexity. The case studies demonstrate that addressing supply chain complexity requires a more thoughtful approach which considers the nature of the response and the attitude of managers to its competitive aspects.

Our findings are among the first to demonstrate the link between the ambidextrous approach of managers within and across organizational boundaries and their responses to supply chain complexity. Managerially, the case study respondents had a complementary perspective through addressing both the internal process and resource issues while exploring and exploiting the supply chain. These activities highlight the need for further research to develop knowledge on how to implement and establish ambidexterity in the management of supply chain complexity.

Fourth, the idea of complexity pre-emption appears valuable, since some activities (such as relationship-building) may prevent future complexities arising. Pre-emption relies on key decision-makers' ability to "see the future" (Fawcett and Waller, 2014, p. 17) and avoid potential issues. The notion of responding to complexities is established, but practices that might reduce the likelihood of occurrence may be useful to explore further. Understanding the conditions which support the development of pre-emptive actions that can aid managers and organizations to avoid the impact of increasing supply chain complexity is an important subject for future research.

Finally, the ideas incorporated in our descriptive framework offer a structured approach for supply chain professionals to discuss and analyse complexities, specifically to identify: (a) the type of complexity; (b) the form of the response; (c) whether the complexity should be reduced or accommodated; and (d) the degree of novelty anticipated to be necessary. This appears to be a valuable technique for managerial teams to use to promote a controlled approach to complexity analysis and response.

\subsection{Implications for teaching}

Complexity provides a bridge between project and supply chain management and highlights the similarities and differences between the two subjects often taught as separate 
aspects within operations management programmes. It also offers students and managers a way to consider the wider impact of potential new business strategies on the supply chain, which can give insights into the challenges that the organization may face.

Most undergraduate courses in operations and supply chain management emphasise the reduction of variability, especially in discussions related to quality management and lean production. As a result, students may leave with the perception that operations' natural role is one of fighting and/or reducing complexity. This paper, through its distinction between beneficial and deleterious complexity, can be used to help undergraduate and graduate students start thinking about the differences between 'good' versus 'bad' variability and complexity, and the broader mission of operations and supply chain to support the business strategy.

In terms of practitioner teaching, we have used these concepts with executive teams and in executive education, and their feedback is that these are valuable frameworks with which to explore approaches to complexity. They provoke meaningful discussions which allow multiple options to be debated. Similarly, supply chain management professionals can choose to reduce/remove or accommodate complexity within their operations and across their upstream and downstream interfaces. The logic of strategically choosing to make their operations more complex appears more palatable when framed in the light of the ensuing competitive advantage. The incorporation of exploitation and exploration is particularly valuable when considering how complexities are to be approached, as this generates a deeper discussion of whether existing approaches can be utilised or whether innovative solutions may be more appropriate.

Our experience indicates that the concepts are readily understood in terms of their practical application and that this represents a valuable addition to the curriculum of managers facing a range of complexities in their work.

\section{Conclusions and Limitations}

We hope that the SCM and project complexity concepts discussed here can lead to further cross-fertilisation between these two literatures to the benefit of researchers and managers. Utilising the complexity framework to categorise and analyse the forms of complexity provides greater clarity to the responses taken by managers faced with increasing levels of supply chain complexity, expanding the understanding of complexity beyond the structural and emergent dimensions of previous supply chain research. The perspective of 
ambidexterity at the individual managerial level as well as organizational level provided further insights into the approaches that can be deployed to exploit processes to counter the deleterious aspects of complexity while exploring internal and external integration approaches to satisfy the organizational strategy. Providing a managerial-level analysis enriches the standard network- or organizational-level supply chain approach. Engaging with the theoretical concepts and approaches used by another academic discipline has proven to be useful in developing contributions to the challenging supply chain complexity issues faced by academics and practitioners.

In practical terms we hope that this provokes debate amongst supply chain practitioners and also within SC teams. It is unclear whether there is a 'right' way to manage complexities, whether guidelines are a feasible target for future research, or whether responses are necessarily too contextual for prescription to be warranted. The framework we presented here is intended to enable discussions and allow experienced professionals to collaborate in finding the most appropriate solutions to the challenges they face. The framework itself does not offer a panacea, instead it allows a structured debate from which solutions can be identified, agreed and shared. It relies upon managerial expertise but the seemingly straightforward questions can lead to new insights and solutions.

The work presented necessarily has limitations. The case studies were initially intended to test the PM framework in a new context and with a small number of cases the findings are far from definitive, leaving numerous avenues to progress this investigation. The cases included multiple SMEs and it is not clear what the results would be in different contexts. Further work can look at larger organizations as the Move Co. case study provided a greater number of socio-political aspects compared to the other organizations. The predominance of SME's may have precluded insights into cross-departmental issues arising within large diversified firms. Further research could also examine specific sectors to identify if there are significant contextual factors which influence a firm's ability to utilise ambidexterity in managing supply chain complexity. This study sheds some light on internal socio-political complexity, however, we still have limited insights into the processes and procedures which may be used to manage this form of complexity. It is also not clear whether or not there are identifiable patterns in terms of complexity response, and future studies may aid our understanding of this issue.

A detailed study of the utility of the frameworks in dealing with complexities and an assessment of the benefits identified would also appear to be helpful, as would a clearer understanding of the circumstances under which responses lead to a successful or 
unsuccessful outcome. At present these remain under-investigated. We hope this work can be built upon by other researchers both to enhance our understanding of supply chain complexity theory and practice, and to provide insight and guidance for managers to apply to their work to help them and their teams with the complexities they face every day.

\section{Acknowledgements}

We would like to thank the anonymous reviewers for their helpful comments on earlier versions of this paper, and we would especially like to express our gratitude to Professor Jack Meredith for his insightful and detailed advice and assistance throughout the review process.

\section{$\underline{\text { References }}$}

Ackoff, R. (1979) "The Future of Operational Research is Past" Journal of the Operational Research Society, Vol. 30 No. 2, pp. 93-104.

Aitken, J., Bozarth, C. and Garn, W. (2016), "To Reduce or Absorb Supply Chain Complexity: A Conceptual Model and Case Study", Supply Chain Management: An International Journal, Vol. 21 No. 6 pp. 759-774

Ashmos, D. and Duchon, D. (2000), "Organizational responses to complexity; the effect on organizational performance", Journal of Organizational Change Management, Vol. 13 No. 6, pp. 577-594.

APM (2012), Body of Knowledge, Sixth ed. Association for Project Management, High Wycombe, UK.

Baccarini, D. (1996), "The concept of project complexity - a review", International Journal of Project Management, Vol. 14 No. 4, pp. 201-204.

Barratt, M., Choi, T. and Li, M. (2011), "Qualitative case studies in operations management: Trends, research outcomes, and future research implications", Journal of Operations Management, Vol. 29 No. 4, pp. 329-342.

Birkinshaw, J. and Gupta, K. (2013), "Clarifying the distinctive contribution of ambidexterity to the field of organization studies". The Academy of Management Perspectives, Vol. 27 No. 4, pp.287-298.

Blome, C., Schoenherr, T. and Kaesser, M. (2013), “Ambidextrous governance in supply chains: The impact on innovation and cost performance", Journal of Supply Chain Management, Vol. 49 No.4, pp 59- 80

Bode, C. and Wagner, S.M. (2015), "Structural drivers of upstream supply chain complexity and the frequency of supply chain disruptions", Journal of Operations Management, Vol. 36, pp. 215-228.

Bozarth, C., Warsing, D., Flynn, B. and Flynn, J. (2009), "The impact of supply chain complexity on manufacturing plant performance", Journal of Operations Management, Vol. 27 No. 1, pp 78-93.

Brady, T. and Davies, A. (2004), "Building Project Capabilities: From Exploratory to Exploitative Learning”, Organization Studies, Vol. 25 No. 9, pp. 1601-1621. 
Chakraborty, S. (2016), "Linking Supply Chain Network Complexity to Interdependence and Risk-Assessment: Scale Development and Empirical Investigation”. Verslas: teorija ir praktika, Vol.17 No. 1, pp.1-12.

Chaos Report (2015), The Standish Group, West Yarmouth, MA.

Childerhouse, P. and Towill, D.R. (2004), "Reducing uncertainty in European supply chains", Journal of Manufacturing Technology Management, Vol. 15 No. 7, pp. 585-598

Choi, T.Y. and Krause, D.R. (2006), "The supply base and its complexity: Implications for transaction costs, risks, responsiveness, and innovation", Journal of Operations Management, Vol. 24 No. 5, pp.637-652.

Cicmil, S., Cooke-Davies, T., Crawford, L., Richardson, K. (2009), Exploring the complexity of projects: Implications of complexity theory for project management practice. Newtown Square, PA: PMI.

De Leeuw, S., Grotenhuis, R. and van Goor, A. (2013), “Assessing complexity of supply chains: evidence from wholesalers", International Journal of Operations and Production Management, Vol. 33 No. 8, pp. 960-980.

Dvir, D., and Shenhar, A. (1998), "In search of project classification: a non-universal approach to project success factors". Research Policy. Vol. 27 No. 9, pp 915-935.

Dybå, T., Dingsøyr, T. (2008), "Empirical studies of agile software development: A systematic review", Information and software technology. Vol. 50 No. 9, pp. 833-859.

Engelbrecht, J., Johnston, K. and Hooper, V. (2017), "The influence of business managers' IT competence on IT project success." International Journal of Project Management, Vol. 35 No. 6, pp. 994-1005.

Fawcett, S.E. and Waller, M.A. (2014), "Can we stay ahead of the obsolescence curve? on inflection points, proactive preemption, and the future of supply chain management". Journal of Business Logistics, Vol. 35 No. 1, pp.17-22

Fisher, M. (1997), "What is the right supply chain for your product?", Harvard Business Review, Vol. 75 No. 2, pp. 105-116.

Flynn, B.B., Huo, B. and Zhao, X. (2010), "The impact of supply chain integration on performance: A contingency and configuration approach", Journal of Operations Management, Vol. 28 No. 1, pp.58-71.

Flyvbjerg B. and Budzier A. (2011), "Why your IT project may be riskier than you think", Harvard Business Review, Vol. 89 No. 9, pp23-25

Frizelle, G. and Woodcock, E. (1995), "Measuring complexity as an aid to developing operational strategy". International Journal of Operations and Production Management, Vol. 15 No. 5, pp.26-39.

Frohlich, M.T. and Westbrook, R. (2001), "Arcs of integration: an international study of supply chain strategies”, Journal of Operations Management, Vol. 19 No. 2, pp.185-200.

Fynes, B. and Voss, C. (2002), "The moderating effect of buyer-supplier relationships on quality practices and performance", International Journal of Operations and Production Management, Vol. 22 No. 6, pp. 589-613.

Ge, H., Nolan, J., Gray, R., Goetz, S. and Han, Y. (2016), "Supply chain complexity and risk mitigation-A hybrid optimization-simulation model", International Journal of Production Economics, Vol. 179, pp.228-238.

Geraldi J., Kutsch E. and Turner N. (2011), "Towards a conceptualisation of quality in information technology projects', International Journal of Project Management, Vol. 29 No. 5, pp. 557-567.

Geraldi, J.G., Maylor, H., Williams, T. (2011), "Now, let's make it really complex (complicated): A systematic review of the complexities of projects', International Journal of Operations and Production Management, Vol. 31 No. 9, pp. 966-990. 
Gibson, C.B. and Birkinshaw, J. (2004), "The antecedents, consequences, and mediating role of organizational ambidexterity", Academy of Management Journal, Vol.47 No. 2, pp.209-226.

Giminez, C., van der Vaart, T and van Donket, P. (2012), "Supply chain integration and performance: the moderating effect of supply complexity", International Journal of Operations and Production Management, Vol. 32 No. 5, pp. 583-610

Gottfredson, M. and Aspinall, K. (2005), "Innovation versus complexity", Harvard Business Review, Vol. 83 No. 11, pp.62-71.

Gunasekaran, A., Subramanian, N. and Rahman, S. (2015), "Green supply chain collaboration and incentives: Current trends and future directions", Transportation Research Part E: Logistics and Transportation Review, Vol. 74, pp.1-10.

Hayes, R.H. and Wheelwright, S.C. (1979), "Link manufacturing process and product life cycles", Harvard Business Review, Vol. 57 No. 1, pp.133-140.

Heim, G., Peng, D. and Jayanthi, A. (2014), "Longitudinal analysis of inhibitors of manufacturer delivery performance", Decision Sciences, Vol. 45 No. 6, pp. 1117-1158.

Highsmith J. (2009), 'Agile Project Management: Creating Innovative Products', Upper Saddle River, NJ, Addison-Wesley

Hoole, R. (2005), "Five ways to simplify your supply chain", Supply Chain Management: An International Journal, Vol.10 No. 1, pp. 3-6.

Huatuco, L.H., Burgess, T.F. and Shaw, N.E. (2010), "Entropic-related complexity for reengineering a robust supply chain: a case study", Production Planning and Control, Vol.21 No. 8, pp.724-735.

Inman, R.R. and Blumenfeld, D.E. (2014), "Product complexity and supply chain design", International Journal of Production Research, Vol. 52 No. 7, pp.1956-1969.

Isik,F. (2010), "An entropy-based approach for measuring complexity in supply chains", International Journal of Production Research, Vol. 48 No. 12, pp 3681-3696

Ivert , L.K. and Jonsson, P (2014), "When should advanced planning and scheduling systems be used in sales and operations planning?", International Journal of Operations and Production Management, Vol. 34 No. 10, pp.1338 - 1362

Jaafari, A. (2003), "Project management in the age of complexity and change", Project Management Journal. Vol. 34 No. 4, pp. 47-57.

Junni, P., Sarala, R.M., Taras, V. and Tarba, S.Y. (2013)," Organizational ambidexterity and performance: A meta-analysis", The Academy of Management Perspectives, Vol. 27 No. 4, pp.299-312.

Ketokivi, M., and Choi, T. (2014), Renaissance of case research as a scientific method. Journal of Operations Management, Vol. 32 No. 5, pp. 232-240.

King N. (2004), Using templates in the thematic analysis of text. In: Cassell C and Symon G (eds) Essential Guide to Qualitative Methods in Organizational Research. London: SAGE, 256-270.

Kristal, M.M., Huang, X. and Roth, A.V. (2010), "The effect of an ambidextrous supply chain strategy on combinative competitive capabilities and business performance", Journal of Operations Management, Vol. 28 No. 5, pp.415-429.

Liu, L., Leitner, D. (2012), "Simultaneous Pursuit of Innovation and Efficiency in Complex Engineering Projects-A Study of the Antecedents and Impacts of Ambidexterity in Project Teams", Project Management Journal. Vol. 43 No. 6, pp., 97-110.

Manuj, I. and Sahin, F. (2011), "A model of supply chain and supply chain decision-making complexity”. International Journal of Physical Distribution \& Logistics Management, Vol. 41 No. 5, pp.511-549.

March, J. G. (1991), "Exploration and Exploitation in Organizational Learning”. Organization Science, Vol. 2 No. 1, pp. 71-87 
Masson R., Iosif,L., MacKerron, G. and Fernie, J. (2007), "Managing complexity in agile global fashion industry supply chains", The International Journal of Logistics Management, Vol. 18 No. 2, pp. 238-254

Maylor, H., Turner, N., Murray-Webster, R. (2013), "How hard can it be? Actively managing complexity in technology projects", Research Technology Management. Vol. 56 No. 4, pp. 45-51.

Maylor H. and Turner N. (2017), "Understand, Reduce, Respond. Project Complexity Management Theory And Practice". International Journal of Operations and Production Management, Vol. 37 No. 8, pp.1076-1093.

Meredith, J. (1998), Building operations management theory through case and field research. Journal of Operations Management, Vol. 16 No. 4, pp. 441-454.

Meredith, J., Mantel, S. (2012), Project Management: A Managerial Approach. 8th edition. Hoboken, NJ: John Wiley.

Miles, M. and Huberman, A. (1984), Qualitative data analysis, Beverley Hills, CA: Sage Publications

Novak, S. and Eppinger, S. (2001), "Sourcing by design: Product complexity and the supply chain ", Management Science, Vol. 47 No. 1, pp. 189-204

Nemanich, L. A. and Vera, D. (2009), 'Transformational leadership and ambidexterity in the context of an acquisition', Leadership Quarterly, Vol. 20 No 1, pp. 19-33.

O Reilly, C.A. and Tushman, M.L. (2004), "The ambidextrous organization", Harvard Business Review, Vol. 82 No. 4, pp.74-83.

O'Reilly, C.A. and Tushman, M.L. (2013), "Organizational ambidexterity: Past, present, and future", The Academy of Management Perspectives, Vol. 27 No. 4, pp.324-338.

Park, J.-G. and Lee, J. (2014), "Knowledge sharing in information systems development projects: Explicating the role of dependence and trust.", International Journal of Project Management, Vol. 32 No. 1, pp. 153-165.

Patel, P.C., Terjesen, S. and Li, D. (2012), "Enhancing effects of manufacturing flexibility through operational absorptive capacity and operational ambidexterity", Journal of Operations Management, Vol. 30 No. 3, pp.201-220.

Pellegrinelli S., Murray-Webster R. and Turner N. (2015), 'Facilitating Organizational Ambidexterity through the Complementary Use of Projects and Programs' International Journal of Project Management Vol.33 No. 1, pp. 153-164.

Perona, M. and Miragliotta, G. (2004), "Complexity management and supply chain performance assessment. A field study and a conceptual framework", International Journal of Production Economics, Vol. 90 No. 1, pp. 103-115.

Pich, M., Loch, C. and De Meyer A. (2002), "On Uncertainty, Ambiguity, and Complexity in Project Management”, Management Science, Vol 48 No. 8, pp.1008-1023.

PMI, (2017), A guide to the project management body of knowledge PMBOK, sixth ed. Project Management Institute, Pennsylvania, USA.

Poutanen, P, Soliman, W. and Stahle, P. (2016), "The complexity of innovation: an assessment and review of the complexity perspective", European Journal of Innovation Management, Vol. 19 No. 2, pp 189-213

Ramasesh, R.V. and Browning, T.R. (2014) "A conceptual framework for tackling knowable unknown unknowns in project management", Journal of Operations Management, Vol. 32 No. 4, pp. 190-204.

Sarpong, S. (2014), "Traceability and supply chain complexity: confronting the issues and concerns", European Business Review, Vol. 26 No. 3, pp.271-284.

Schoenherr, T. and Swink, M. (2012), "Revisiting the arcs of integration: Cross-validations and extensions", Journal of Operations Management, Vol. 30 No. 1, pp.99-115. 
Secchi, R. and Camuffo, A. (2016), "Rolling out lean production systems: a knowledge-based perspective", International Journal of Operations and Production Management, Vol. 36 No. 1, pp.61-85

Seifert, D. (2003), Collaborative planning, forecasting, and replenishment: How to create a supply chain advantage. AMACOM Div American Mgmt Assn.

Serdarasan, S. (2013), "A review of supply chain complexity drivers", Computers \& Industrial Engineering, Vol. 66 No. 3, pp.533-540.

Shenhar A. and Holzmann V. (2017), "The Three Secrets of Megaprojects Success: Clear Strategic Vision, Total Alignment, and Adapting to Complexity", Project Management Journal (forthcoming).

Squire, B., Cousins, P., Lawson, B. and Brown, S. (2009), "The effect of supplier manufacturing capabilities on buyer responsiveness", International Journal of Operations and Production Management, Vol.29 No.8, pp 66-788

Taylor, D and Fearne, A. (2006), "Towards a framework for improvements of the management of demand in agri-food supply chains", Supply Chain Management: An International Journal, Vol.11 No.5, pp 379-384

Thomé, A., Scavarda, L., Scavarda, A. and de Souza T. (2015), "Similarities and contrasts of complexity, uncertainty, risks, and resilience in supply chains and temporary multiorganization projects", International Journal of Project Management. Vol.34 No. 7, pp 1328- 1346

Turner N. and Lee-Kelley L. (2013), 'Unpacking the theory on ambidexterity: an illustrative case on the managerial architectures, mechanisms and dynamics.' Management Learning, Vol. 44 No. 2, pp. 179-196.

Turner, N., Swart, J. and Maylor, H. (2013), "Mechanisms for managing ambidexterity: A review and research agenda" International Journal of Management Reviews, Vol.15 No. 3, pp.317-332.

Turner N., Swart J., Maylor H. and Antonacopoulou E. (2016), "Making it happen: how managerial actions enable project-based ambidexterity", Management Learning Vol 47 No. 2, pp. 199-222.

Tushman, M.L. and O'Reilly, C.A. (1996), "The ambidextrous organizations: Managing evolutionary and revolutionary change", California Management Review, Vol. 38 No.1. pp.8-30.

Uhl-Bien, M. Marion, R. and McKelvey, B. (2007) “Complexity Leadership Theory: Shifting leadership from the industrial age to the knowledge era", The Leadership Quarterly, Vol 18, No. 4, pp. 298-318

Vachon, S. and Klassen, R.D. (2002), “An exploratory investigation of the effects of supply chain complexity on delivery performance", IEEE Transactions on Engineering Management, Vol. 49 No. 3, pp. 218-230.

Voss, C., Tsikriktsis, N., and Frohlich, M. (2002), "Case research in operations management", International Journal of Operations and Production Management, Vol. 22 No. 2, pp. 195-219.

Williams, T. (2005), "Assessing and Moving on From the Dominant Project Management Discourse in the Light of Project Overruns", IEEE Transactions on Engineering Management, Vol. 52 No. 4, pp. 497-508.

Wilding, R. (1998), "The supply chain complexity triangle: uncertainty generation in the supply chain", International Journal of Physical Distribution \& Logistics Management, Vol. 28 No. 8, pp.599-616.

Wong, C.W., Wong, C.Y. and Boon-itt, S. (2013), "The combined effects of internal and external supply chain integration on product innovation", International Journal of Production Economics, Vol. 146 No. 2, pp.566-574. 
Wu, Y.R., Huatuco, L.H., Frizelle, G. and Smart, J. (2013), "A method for analysing operational complexity in supply chains". Journal of the Operational Research Society, Vol. 64 No. 5, pp.654-667.

Xia, W. and Lee, G. (2005), "Complexity of information systems development projects: conceptualization and measurement development", Journal of management information systems, Vol. 22 No. 1, pp.45-83.

Yang, B, Yang, Y and Wijngaard, J. (2007), "Postponement: an inter-organizational perspective", International Journal of Production Research, Vol. 45 No. 4, pp. 971-988.

Yin, R.K., (2014). Case Study Research. Design and Methods. Fifth Edition 


\section{Dimensions of Complexity}

\begin{tabular}{|c|c|c|c|c|}
\hline & & Structural & Socio-political & Emergent \\
\hline & $\begin{array}{l}\text { Planning } \\
\text { and control }\end{array}$ & $\begin{array}{l}\text { Initiating, planning, } \\
\text { monitoring (e.g. } \\
\text { applying Earned } \\
\text { Value systems). } \\
\text { Using an Integrated } \\
\text { Master Schedule. }\end{array}$ & $\begin{array}{l}\text { Develop a } \\
\text { communications plan. } \\
\text { Establish project } \\
\text { board of } \\
\text { stakeholders. }\end{array}$ & $\begin{array}{l}\text { Apply risk } \\
\text { management and } \\
\text { change control } \\
\text { processes. }\end{array}$ \\
\hline $\begin{array}{l}\text { Complexity } \\
\text { Management } \\
\text { Responses }\end{array}$ & $\begin{array}{l}\text { Relationship } \\
\text { development }\end{array}$ & $\begin{array}{l}\text { Prioritise } \\
\text { communications with } \\
\text { stakeholders. } \\
\text { Conduct project } \\
\text { outreach activities. }\end{array}$ & $\begin{array}{l}\text { Engage in } \\
\text { teambuilding } \\
\text { activities. } \\
\text { Invest in social } \\
\text { capital. }\end{array}$ & $\begin{array}{l}\text { Socialise changes. } \\
\text { Increase informal } \\
\text { communications. }\end{array}$ \\
\hline & Flexibility & $\begin{array}{l}\text { Embrace changes } \\
\text { from process. } \\
\text { Anticipate change. } \\
\text { Enable parallel } \\
\text { development. }\end{array}$ & $\begin{array}{l}\text { Manage expectations } \\
\text { of change. } \\
\text { Engage in joint look- } \\
\text { ahead planning with } \\
\text { major stakeholders. }\end{array}$ & $\begin{array}{l}\text { Use Agile PM } \\
\text { approaches. } \\
\text { Encourage } \\
\text { entrepreneurial PM. }\end{array}$ \\
\hline
\end{tabular}

Table 1: Relating project complexities to management responses (Maylor and Turner, 2017, p. 1086) 


\section{Dimensions of Complexity}

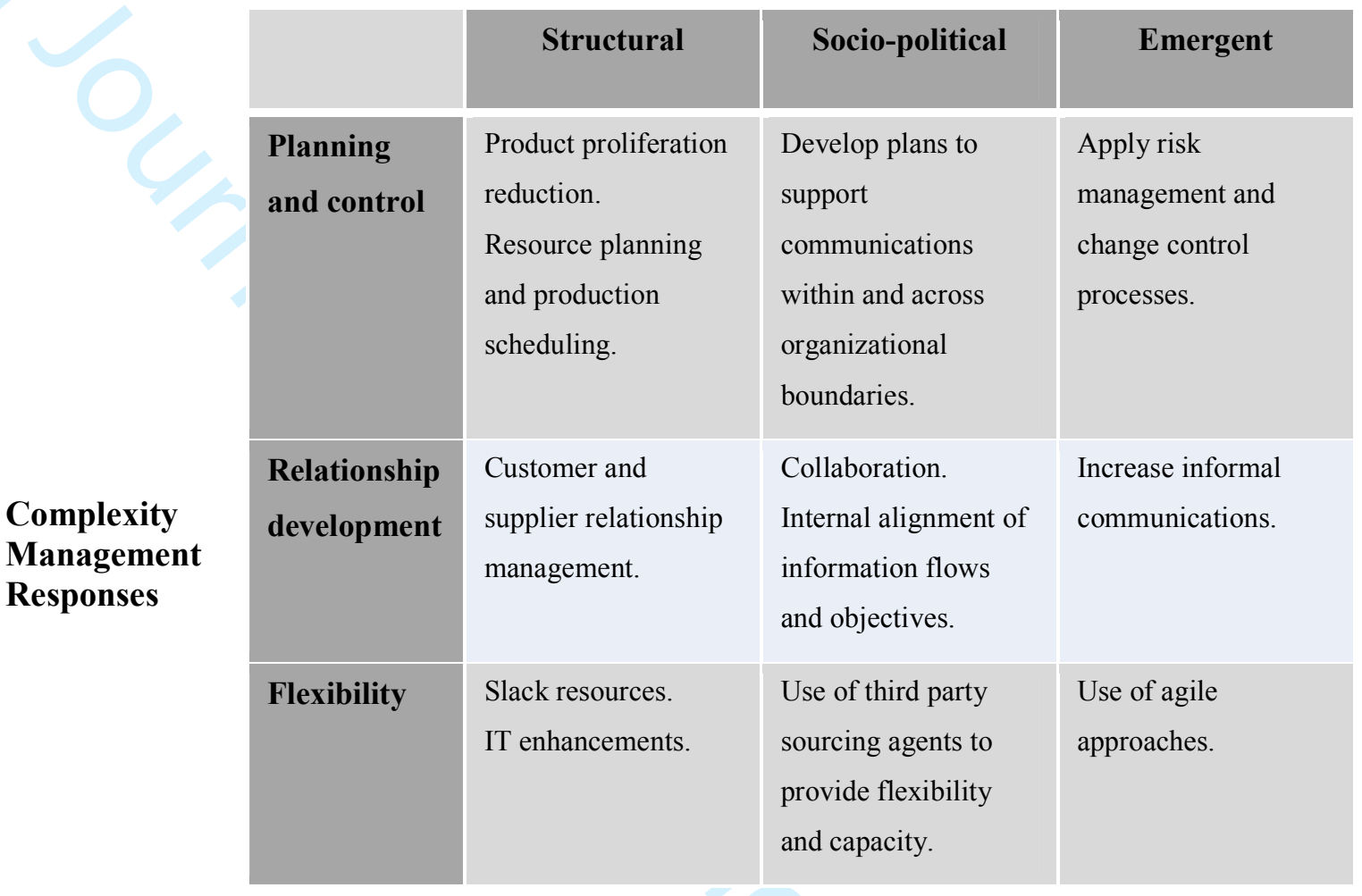

Table 2: Relating supply chain complexities to management responses, adapted from Maylor and Turner (2017) 


\begin{tabular}{|c|c|c|}
\hline & $\begin{array}{l}\text { Exploit } \\
\text { Refining and using existing } \\
\text { knowledge }\end{array}$ & $\begin{array}{l}\text { Explore } \\
\text { Innovating, problem-solving and } \\
\text { creating new knowledge }\end{array}$ \\
\hline $\begin{array}{l}\text { Deleterious } \\
\text { complexity } \\
\text { (Reduce) }\end{array}$ & $\begin{array}{l}\text { Use appropriate known technology } \\
\text { / process / best practice to reduce } \\
\text { the complexity. } \\
\text { Example - Use established } \\
\text { business rules to trim the number } \\
\text { of product offerings. }\end{array}$ & $\begin{array}{l}\text { Develop or bring in a solution to reduce or } \\
\text { eliminate the complexity. } \\
\text { Example - Implement advanced scheduling } \\
\text { software to stabilise production schedules. }\end{array}$ \\
\hline $\begin{array}{c}\text { Beneficial } \\
\text { complexity } \\
\text { (Accommodate) }\end{array}$ & $\begin{array}{l}\text { Build on existing solutions to gain } \\
\text { the benefits available from the } \\
\text { complexity. } \\
\text { Example - Modify existing } \\
\text { product designs to provide more } \\
\text { offerings to customers. }\end{array}$ & $\begin{array}{l}\text { Work in a new way to take advantage of a } \\
\text { complex opportunity that competitors find } \\
\text { difficult to emulate. } \\
\text { Example - Work with a wider range of } \\
\text { suppliers and intermediaries to enable more } \\
\text { new product variations to a greater number } \\
\text { of customers. }\end{array}$ \\
\hline
\end{tabular}

Table 3: Relating exploitative/exploratory responses to reduction/accommodation of supply chain complexity 


\begin{tabular}{|c|c|c|c|c|}
\hline $\begin{array}{l}\text { Company } \\
\text { Name }\end{array}$ & Revenue & $\begin{array}{l}\text { Number of } \\
\text { Employees }\end{array}$ & $\begin{array}{l}\text { Functional role (years } \\
\text { with firm) }\end{array}$ & Data Collection \\
\hline $\begin{array}{l}\text { Food Co. } \\
\text { (FC) }\end{array}$ & $\begin{array}{l}£ 85 \mathrm{~m} \text { (part of } \\
\text { group with } \\
£ 2.1 \text { bn } \\
\text { turnover) }\end{array}$ & $\begin{array}{l}180 \text { (group: } \\
7000+\text { ) }\end{array}$ & $\begin{array}{l}\text { Operations Director (18) } \\
\text { Production Manager } \\
(12) \\
\text { Production Supervisor } \\
(20) \\
\text { Planning Control } \\
\text { Manager (7) } \\
\text { Production Planner (2) } \\
\text { Buyer (6) }\end{array}$ & $\begin{array}{l}\text { Data collected } \\
\text { January - February } \\
2016 \\
\text { Duration of } \\
\text { interviews was } \\
\text { between } 60-90 \\
\text { minutes }\end{array}$ \\
\hline $\begin{array}{l}\text { Move Co. } \\
\text { (MC) }\end{array}$ & $£ 500 \mathrm{~m}+$ & $10,000+$ & $\begin{array}{l}\text { RDC manager (25) } \\
\text { Operations Manager } \\
\text { (18) } \\
\text { Logistics Manager (28) } \\
\text { Improvement Manager } \\
(14)\end{array}$ & $\begin{array}{l}\text { Data collected } \\
\text { January } 2016 . \\
\text { Duration of } \\
\text { interviews was 60- } \\
90 \text { minutes }\end{array}$ \\
\hline $\begin{array}{l}\text { Restore } \\
\text { Co. (RC) }\end{array}$ & $£ 2.4 \mathrm{~m}$ & 14 & $\begin{array}{l}\text { Managing Director (10) } \\
\text { Materials Manager (5) } \\
\text { Production Manager (1) } \\
\text { Engineering Director (2) }\end{array}$ & $\begin{array}{l}\text { Data collected in } \\
\text { May } 2016 \\
\text { Duration of } \\
\text { interviews } 45-60 \\
\text { minutes }\end{array}$ \\
\hline $\begin{array}{l}\text { Wood Co. } \\
\text { (WC) }\end{array}$ & $£ 1.0 \mathrm{~m}$ & 8 & $\begin{array}{l}\text { Managing Director (25) } \\
\text { Customer Services } \\
\text { Manager (6) }\end{array}$ & $\begin{array}{l}\text { Data collected in } \\
\text { May } 2016 \\
\text { Duration of } \\
\text { interviews } 45-60 \\
\text { minutes }\end{array}$ \\
\hline $\begin{array}{l}\text { Crash Co. } \\
\text { (CC) }\end{array}$ & $£ 3.2 \mathrm{~m}$ & 24 & $\begin{array}{l}\text { Operations Director (8) } \\
\text { Commercial Director } \\
(10) \\
\text { Estimator (5) } \\
\text { Parts Manager (2) }\end{array}$ & $\begin{array}{l}\text { Data collected in } \\
\text { June } 2016 \\
\text { Duration of } \\
\text { interviews } 30-60 \\
\text { minutes }\end{array}$ \\
\hline $\begin{array}{l}\text { Light Co. } \\
\text { (LC) }\end{array}$ & $£ 15 \mathrm{~m}$ & 82 & $\begin{array}{l}\text { Operations Director (26) } \\
\text { Finance Director (10) } \\
\text { Buyer (2) } \\
\text { Planning and Control } \\
\text { Manager (9) }\end{array}$ & $\begin{array}{l}\text { Data collected in } \\
\text { June } 2016 \\
\text { Duration of } \\
\text { interviews } 45-90 \\
\text { minutes } \\
\end{array}$ \\
\hline
\end{tabular}

Table 4: Case data and respondents for case interviews 


\begin{tabular}{|c|c|c|c|}
\hline & Structural (65\%) & Socio-political (12\%) & Emergent (23\%) \\
\hline $\begin{array}{l}\text { Planning and } \\
\text { control } \\
(56 \%)\end{array}$ & $\begin{array}{l}\text { Quality issues with a } \\
\text { particular product, choose to } \\
\text { avoid.(WC) } \\
\text { Look at supplier } \\
\text { accreditation details to assess } \\
\text { conformance ability.(FC) } \\
\text { Supplier selection based on } \\
\text { demonstrated quality.(CC) } \\
\text { Planning for 10-15k } \\
\text { collection points per } \\
\text { day.(MC) }\end{array}$ & $\begin{array}{l}\text { Build better relationships with } \\
\text { key clients by offering custom, } \\
\text { repeatable, solutions that they } \\
\text { value but didn't expect.(CC) } \\
\text { Losing 'bad' frictional clients } \\
\text { that cause stress.(CC) }\end{array}$ & $\begin{array}{l}\text { Bring on other suppliers to } \\
\text { accommodate spikes in } \\
\text { demand.(FC) } \\
\text { Small suppliers getting old } \\
\text { and retiring/dying. Having to } \\
\text { bring those capabilities in- } \\
\text { house.(RC) } \\
\text { Scheduling one-off pick-up } \\
\text { requests as they occur.(MC) }\end{array}$ \\
\hline $\begin{array}{l}\text { Relationship } \\
\text { development } \\
(17 \%)\end{array}$ & $\begin{array}{l}\text { Small team can make } \\
\text { compromises and solve } \\
\text { problems quickly and locally } \\
\text { rather than going up the } \\
\text { hierarchy.(FC) } \\
\text { Good relationship with long- } \\
\text { term suppliers means they } \\
\text { know what questions to ask } \\
\text { about a new design.(FC) }\end{array}$ & $\begin{array}{l}\text { Need to get work prioritised } \\
\text { with suppliers, helped by } \\
\text { building relationships.(RC) } \\
\text { Clear, well-understood, overall } \\
\text { prioritisation is beneficial when } \\
\text { departments have different } \\
\text { goals.(MC) }\end{array}$ & $\begin{array}{l}\text { Strong relationship with } \\
\text { customers built up over years } \\
\text { allows unforeseen delays to } \\
\text { be accepted more } \\
\text { readily.(WC) } \\
\text { Finding new suppliers via } \\
\text { networking.(WC) }\end{array}$ \\
\hline $\begin{array}{l}\text { Flexibility } \\
(27 \%)\end{array}$ & $\begin{array}{l}\text { Weekly production planning } \\
\text { is reviewed and adjusted } \\
\text { daily as required.(FC) } \\
\text { Bespoke solutions to part } \\
\text { requirements - needs } \\
\text { judgement as to the level of } \\
\text { specification needed for a } \\
\text { particular car part.(RC) }\end{array}$ & $\begin{array}{l}\text { Need to meet key customer } \\
\text { relationship demands by } \\
\text { responding swiftly, e.g. to } \\
\text { changes in their processes.(CC) } \\
\text { Planning team get more } \\
\text { knowledge about the product, } \\
\text { and understanding of the real } \\
\text { demands rather than just } \\
\text { relying on forecasts.(FC) }\end{array}$ & $\begin{array}{l}\text { Having to be creative in } \\
\text { production planning due to a } \\
\text { factory fire reducing overall } \\
\text { capacity.(FC) } \\
\text { Having to source suitable } \\
\text { parts for obsolete or modified } \\
\text { cars.(CC) } \\
\text { Rescheduling delivery routes } \\
\text { due to unexpected } \\
\text { flooding.(MC) }\end{array}$ \\
\hline
\end{tabular}

Table 5: Examples: supply chain complexities and management responses. 


\begin{tabular}{|c|c|c|}
\hline & $\begin{array}{c}\text { Exploit } \\
\text { Refining and using existing } \\
\text { knowledge }(67 \%)\end{array}$ & $\begin{array}{l}\text { Explore } \\
\text { Innovating, problem-solving and } \\
\text { creating new knowledge }(33 \%)\end{array}$ \\
\hline $\begin{array}{c}\text { Deleterious } \\
\text { Complexity } \\
\text { (Reduce) }(63 \%)\end{array}$ & $\begin{array}{l}\text { Structural - Schedule effectively for } \\
\text { busy periods (e.g. Christmas). (MC) } \\
\text { Socio-political - Explain the situation } \\
\text { to customers openly and honestly so } \\
\text { they understand the reasons for delay. } \\
\text { (WC) } \\
\text { Emergent - Fix prices for } 6 \text { months to } \\
\text { contain price and currency } \\
\text { fluctuations. (FC) }\end{array}$ & $\begin{array}{l}\text { Structural - Use a pool of trained temporary } \\
\text { labour to allow flexibility to respond to } \\
\text { demand. (FC) } \\
\text { Socio-political - Try and use network of } \\
\text { contacts to find new suppliers and parts. (RC) } \\
\text { Emergent - Proliferation of new products } \\
\text { means that some do need to be eliminated if } \\
\text { they do not sell as anticipated. (FC) }\end{array}$ \\
\hline $\begin{array}{c}\text { Strategic } \\
\text { Complexity } \\
\text { (Accommodate) } \\
(37 \%)\end{array}$ & $\begin{array}{l}\text { Structural - Use an increasing number } \\
\text { of components to make bespoke } \\
\text { options for customers. (LC) } \\
\text { Socio-political - Customer will try } \\
\text { and find a part on eBay faster than } \\
\text { standard delivery time but it may not } \\
\text { be guaranteed, so RC will try and give } \\
\text { the customer peace of mind with } \\
\text { guaranteed parts. (RC) } \\
\text { Emergent - Accommodate one-off } \\
\text { collection requests as necessary and } \\
\text { schedule alongside regular pick-ups. } \\
\text { (MC) }\end{array}$ & $\begin{array}{l}\text { Structural - Find new offerings from existing or } \\
\text { new suppliers. (WC) } \\
\text { Socio-political - Moving to } 24 \mathrm{hr} \text { production has } \\
\text { meant a major change in shift patterns which } \\
\text { needs to be implemented. (FC) } \\
\text { Emergent - Market demands lots of choice in } \\
\text { product so these need to be developed. (FC) }\end{array}$ \\
\hline
\end{tabular}

Table 6: Exploitative/exploratory responses to supply chain complexities. 